\title{
Construction of Differentiated Periodic Freight Train Paths in Dense Mixed Traffic
}

\author{
Michal Drábek ${ }^{1, *}$ and Vít Janoš ${ }^{2}$
}

1 Czech Technical University in Prague, Faculty of Transportation Sciences, Department of Logistics and Management of Transport, Horská 3, 12803 Praha, Czech Republic; xdrabek@fd.cvut.cz

2 Czech Technical University in Prague, Faculty of Transportation Sciences, Department of Logistics and Management of Transport, Horská 3, 12803 Praha, Czech Republic; janos@fd.cvut.cz

* Correspondence: xdrabek@fd.cvut.cz; Tel.: +420-721-971-072

\begin{abstract}
The article is focused on detailed framework process for hierarchized construction of periodic freight train paths (PFTPs) - allocation of pre-arranged railway capacity to freight rail operators. The framework process considers fluctuations in demand for capacity from freight rail operators, so the quality of a freight train path is related with its construction priority. Introduced framework process aims to offer freight rail operators attractive train paths, with low number of scheduled stops, and this way enhance competitiveness and decrease energy consumption of freight railway as a factor for sustainable development. The proposed generic process is intended for all time horizons of capacity allocation. Correctness of the framework process is tested on the example of mainline Prague - Dresden, in the context of prospective (denser) model passenger timetable.
\end{abstract}

Keywords: Integrated Periodic Timetable (IPT); periodic freight train path (PFTP); train path symmetry; active overtaking; power-to-mass ratio (PMR); sustainable transportation

\section{Introduction}

\subsection{Sustainable Development and Freight Railway}

Rail transport plays key role in the transition to sustainable development, contributing particularly to UN goal 11 - see the list [1], as stated in the UN General Assembly Resolution 70/1. [2] (p.14). In the case of electric traction, which the majority of busiest European mainlines are equipped with, there are zero local emissions. In 2018, the rail share on direct (local) greenhouse gas emissions was only $0.4 \%$ from total emissions of the transport sector [3]. This way, railway helps to meet ambitious goals of emission reduction, as declared in the European Green Deal [4] and the related regulation proposal [5].

Besides passenger transport, freight railway is important for sustainable development as well. It offers high economies of scale, and with adequate timetabling (as little number of stops as possible), the energy consumption per net tonne-kilometre can be comparably low. However, a typical European mainline is mixed-traffic, and three rail segments have to be scheduled there in a coordinated way: long-distance and regional passenger trains and freight trains. Such coordination represents a challenge, since mutually different timetabling requirements of all segments have to be taken into account.

\subsection{Integrated Periodic Timetable}

In Western and Central Europe, railway public transport is commonly offered in the form of periodic timetable (sometimes referred to as clockface timetable). In some countries, periodic service is enhanced to Integrated Periodic Timetable (IPT), which offers travel chains all-day and during whole network, using periodic offer of transfers between 
public transport lines. The best variant of such transfers is an IPT-node, where (ideally) services of all adjoining public transport lines arrive few minutes before symmetry time (usually the minute 00 or few minutes before). Symmetry time is the periodic time when services of some particular public transport line, while running in opposite directions, meet each other (either stopping or not). Around the symmetry time, the node station is full of trains. The passengers can transfer between any two public transport lines [6] (pp. 18-20). Hence, a competitiveness to car - to a certain extent - is assured. IPT-nodes and other periodic transfer connections create spatial availability of the offer. The period creates temporal availability.

Contrary to periodic only timetable, whose only mathematical prerequisite is constant period between subsequent services, IPT requires additional ones. For symmetric transfer processes in both directions, unified symmetry time in the whole public transport network is necessary [6]. This implies symmetric scheduled runtimes in both directions as well.

Arc and cycle equations [6] (pp. 19-20) are another mathematical prerequisites. Given the necessary scheduled runtimes (with added proportions of dwell or transfer times in IPT-nodes and a timetable recovery margin) are feasible, a system travel time, resulting from both equations, is fulfilled (i.e. not exceeded). Then, all IPT nodes en route are reached in time, and the IPT gives the desired effect.

Serafini and Ukovich [7] proposed a mathematical model for scheduling activities of periodic type - Periodic Event Scheduling Problem (PESP). Most of (but not all) quantitative scientific works in the field of IPT were based on this model, for instance Liebchen [8] and Opitz [9] (pp. 95-121).

\subsection{Freight Timetabling Within IPT}

Contrary to extensive research in passenger, especially periodic, timetabling, freight timetabling was solved mostly merely as an additional problem. However, some works dedicated to freight railway timetabling problems emerged as well.

Müller [10] (pp. 11-13, 113-119) verified IPT for wagonload transport in Germany. Marshalling yards were supposed to correspond IPT-nodes. Various automation levels of wagons (automatic coupling, autonomous drive etc.). were considered as well. The result was a calculation that has shown no significant time- or cost-saving potential for such concept with use of conventional freight wagons.

Lindner and von Redern [11] summed up problems with construction of freight train paths in IPT. They found that it was necessary to let periodic time windows ("canals") free for freight trains, giving them sufficient capacity. The result of their proposal was not periodic freight timetable, but periodic freight train paths (PFTPs) - or merely periodic time windows - e.g. 1 or 2 freight train paths for the speed of $90 \mathrm{~km} / \mathrm{h}$ instead of 2 or 3 freight train paths for the speed of $100 \mathrm{~km} / \mathrm{h}$. These time windows should be preferably connected together in nodes (if needed, among more than two lines to enable use by freight trains with various origin/destination stations). A freight train can as well use some particular PFTP only partially.

Caimi et al. [12] proposed mathematical formulation of partially periodic service some train paths can be scheduled in peak times only, and can, if need be, alternate with another (such as freight) train paths - supposed that both train path types fit within fully periodic (all-day) timetable pattern.

Opitz [9] modelled PFTPs with chosen sample freight trains, using "sample train atoms", later referred to as "snippets" [13] (p. 193). With the help of such building block, he was able to distinguish different capacity consumption of otherwise identical freight trains that did or did not stop in a particular station.

Vromans introduced similar approach [14] (p. 186). He explained that the choice whether to stop at a station or not provided much flexibility to his model, and that this option could be used also for determining the optimal location for possible overtakings of freight trains. 
Čapek [15] and Klabes [16] (p. 78) used "bending" of train paths to harmonize speed profiles (i.e. section runtimes) as a part of their approaches, so that efficiency of railway capacity utilization can be improved.

First edition of UIC Code 406 Capacity [17] considered train path heterogeneity (i.e. difference in scheduled section runtimes) one of four key parameters that influence railway capacity (however, the capacity is determined in much more complex way, depending on many factors - see Stoilova et al. [18]). This influence is negative - the higher heterogeneity, the lower line capacity, i.e. the fewer train paths can be scheduled per defined time unit. It is obvious that slower trains have to be overtaken by faster ones, unless the capacity requirements for the line are very low. The thing is, the longer is the section between two overtakings of a slow train, the more potential faster train paths are consumed by a slow train path. Thus, the capacity estimation based on compression of subsequent train paths closely together (with time supplements added to secure quality of operation) gives various results, depending on length of the chosen line section - see the $2^{\text {nd }}$ edition of UIC Code 406 Capacity [19] (pp. 33-34). Positive influence of overtaking tracks on railway capacity was demonstrated, for instance, by Gašparík et al. [20]. However, utilization of such tracks in operation should be verified - ideally by microsimulation, as shown by Čamaj et al. [21], so that investment in additional track can be justified.

Bablinski [22] carried out a set of simulation games based on a real-world scenario where preferential treatment of freight operators was included. However, the author admitted that benefits for freight operators were achieved at the cost of loss of rail system efficiency due to increased level of heterogeneity.

Some authors focus on improvement of process of inserting additional freight train paths into previously determined passenger timetable. Cacchiani et al. [23] proposed to introduce as many new freight trains as possible by assigning them timetables that are as close as possible to the ideal ones (from the operators' viewpoint). Ljunggren et al. [24] introduced an algorithm that maximized the bottleneck robustness by maximizing the temporal distance to neighbouring train paths in the timetable.

Vromans [14] (p. 84) compared approaches for determination of recovery margins (runtime supplements) in chosen countries - for passenger, as well as for freight trains. In Netherlands, the supplements were proportionally allocated with respect to the minimum runtime. He stated that in practice the freight trains were often faster and lighter than planned (and scheduled).

Haldeman [25] described rules for recovery margins in Switzerland. A relative margin was $11 \%$ of the runtime of freight trains. In addition, one-minute margin was added for each 30 minutes of running time. Further, Special Operational Supplements were added, for instance, in busy node areas.

Růžička designed partially periodic freight train paths for public additional locomotive service for freight operators his bachelor thesis [26]. Because of different operation of additional locomotives in both directions, unified symmetry axis was not maintained.

Chýle [27] designed two types of PFTPs on the mainline between Prague and Summerau (for lighter and faster vs. for heavier and slower trains), both in 4-hour periods. However, due to partially periodic passenger services (some services fell out in off-peak times) and long single-track sections, he had to do many adjustments, so the resulting catalogue freight train paths have turned into practically aperiodic - especially in single-track sections.

Rủžička designed PFTPs for busy mainline between Přerov and Petrovice u Karviné in his diploma thesis [28]. Along the whole line, two groups of PFTPs, both with 2-hour period, were designed. Due to imperfect symmetry and many additional peak services in long-distance passenger railway, only one group was constructed with unified (zero) symmetry.

Janoš and Kříž [29] proposed to utilize lost capacity by active overtaking of a slow regional passenger train by fast freight train, given enough high speed ratio of both 
trains. They analysed possibilities of such overtaking on Prague - Děčín mainline. If such overtaking becomes a routinely repeated process, then adequate real-time dispatching will be necessary. One of most serious obstacles to it on most of European rail networks is deficiency in standardized data exchange that would enable accurate prediction of train running, as highligted by Kamenický [30].

\subsection{Network-Bound Periodic Freight Train Paths}

Drábek [31] introduced, to the authors' knowledge, first concept of network-bound freight train paths, scheduled alternatively into two directions from the node station. Given node station with level crossing (without flyovers), timetabling conflict was avoided by different runtime margins, depending on a direction that the freight train should proceed to. So, blocking of the whole switch region at one time did not exclude blocking of the whole switch region by the train path between another directions, which was scheduled at another time. Drábek's approach, which preserves train path symmetry in the end of sections adjoining to the node station, is an analogy to passenger IPT-node, but tailor-made for freight railway. The unified period and (at least outer) unified symmetry has remained common for both concepts, but transfers in passenger transport were replaced by possibility of direct passing through a node (without stopping) by a freight train. Both concepts enable free combination of adjoining directions, but there is another key difference. Passenger IPT offers periodic services, which can be used by passengers (in the part of the service route as a rule, or not at all). Drábek's network-bound offer of PFTPs offers capacity to train operators. Only a part of particular PFTP can be used by a freight train.

Based on this pilot study, Drábek developed in his doctoral thesis ([32]), previously published in [33]) a framework process, which is intended as a building set of measures (i.e. only the appropriate ones should be applied in any particular case). This framework process (Figure 1) comes out from the above-mentioned freight analogy to IPT.

As a conclusion, two measures for efficient capacity utilization are proposed: homogenization of freight trains with the most frequent speed segment of passenger trains (already in the timetabling/allocation phase, unless faster running of freight trains is technically impossible) and avoidance of stopping freight trains in bottlenecks and uphill sections if possible.

Michl, Drábek, Janoš et al. [34], following Drábek's framework process up, proposed systematic homogenization of heterogeneous train paths - already in the phases of capacity allocation and timetabling. Moreover, they proposed speed bundling of homogeneous train paths with the use of bending of freight and (if necessary) long-distance train paths towards longer section runtime. Thus, more efficient speed bundling with most frequent train segment (suburban trains as a rule) is enabled.

Michl et al. segmented train paths based on two criterions - periodicity and degree of advance. Periodic train paths can be either previously allocated ones (based on the operators' requests) or catalogue (pre-arranged) ones - mostly for typical freight trains, whose departure days and times cannot be determined in the timetabling phase, but such trains are reasonably expected to run, based on ad hoc capacity requests.

Individual train paths - both previously allocated and ad hoc ones - must not disrupt all-day (or rush hour) periodic timetabling pattern.

Besides bundling, an appropriate sequence of heterogeneous train paths can save capacity as well. Thus, the fastest train should run as first, then middle-fast train and the slowest train in the end. IPT-based symmetry causes that in each direction this sequence is exactly opposite [34] (pp. 26-31). 


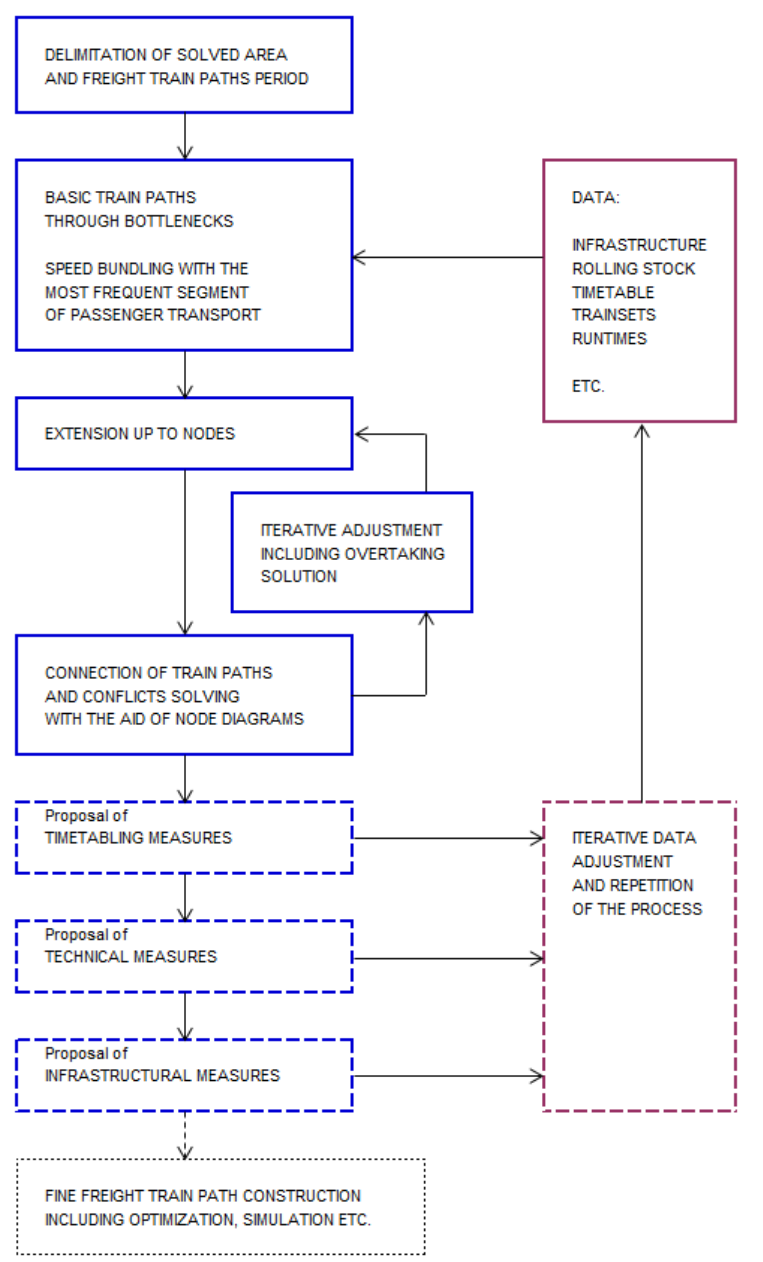

Figure 1. Framework process for construction of network-bound PFTPs. Fine train path construction is not a part of the process [32,33].

By construction of PFTPs one cannot avoid some inherent asymmetry (items 1 to 3 come from Drábek [35]):

1. Local overtaking-based asymmetry in case of steep gradient

2. Local asymmetry based on adding and releasing of assistance locomotive in the uphill direction only (for steep gradient)

3. Asymmetric scheduled stop (only in one direction) of a freight train for crossing

4. In case of sequence of heterogeneous trains, mentioned above, freight train can depart after fast train almost immediately. Contrary, in the opposite direction, some appropriate buffer time between arrivals of freight train and fast train is necessary.

The asymmetry should be maintained as local only - between two nearest node stations where PFTPs branch to more directions. In these stations, PFTPs should be symmetric again, so the asymmetry propagation further through the network is avoided. Only few minutes deviation in symmetry in nodes is permissible, provided that:

1. It is necessary for conflict-free PFTPs scheduling through level crossing (see introduction of a freight IPT-node above);

2. PFTPs can symmetrically proceed further to/from next nodes where PFTPs branch.

Drábek [32] examined modification of passenger timetable on a section between two node stations, for the sake of capacity for catalogue PFTPs on a double-track line with mixed traffic. As a timetable pattern, prospective timetable from Czech research project on configuration of IPT-nodes [36] was used, with 7 long-distance and 2 regional passenger train paths per hour (30 min period) and direction. Intercity train paths were kept untouched. Regional train paths were provisionally removed. Fast (regional express) 
train paths (30 min period) were shifted closer to (i.e. bundled with) intercity train paths. Then, PFTPs (with at most 1 stop per PFTP) and a regional train path were iteratively constructed. The main result, besides 3 PFTPs with 1 overtaking only, was a significant deterioration of regional railway offer - 1 train per hour only and service cancellation for 3 stops. Such solution would be very likely politically unacceptable if applied really.

Drábek [37] estimated maximum net goods mass that can be carried hourly through concept of network-bound PFTPs proposed in [31] and only slightly modified. Container trains were considered. Night capacity for freight trains was not considered. For allowed axle load $22.5 \mathrm{t}$ and comparably small allowed train mass of 1,250 t, considering container trains, the net hourly throughput (excluding tare weight of containers and wagons) was estimated as high as 6,220 t.

\subsection{Problem of a Sample Freight Train for PFTPS}

Another research question is whether there can be scheduled any "typical" freight train path, which can be used as a catalogue PFTP.

Drábek [31] worked out OD-Matrix of freight train paths, according to official timetable at that time. He gathered scheduled section runtimes and compared them with desired runtimes for the proposed PFTPs. Determination of desired runtimes was iterative, influenced by scheduled freight train runtimes. If any section runtime was too short for about half of freight trains, the desired runtimes was lengthened (i.e. relaxed) to the detriment of runtime of neighbouring, non-critical section. The aim of this iteration was prevention of scheduling of too many overtakings for PFTPs. However, some longer sections uphill became critical, and resulted in $70 \%$ of scheduled freight trains that were able to fit in PFTPs (scheduled runtimes for sections between neighbouring stations were assessed, if there was scheduled at most 1 stop). So, remaining $30 \%$ of freight trains were supposed to be scheduled at night or within the remaining capacity.

Kuckelberg et al. [38] introduced clustering algorithm for gaining of sample trains, that was implemented in railway operation research analytical LUKS ${ }^{\circledR}$ system. They clustered all trains, even with different routes, at the same time, and therefore they had to compare several key train parameters, which they enumerated in descending order of importance considering train similarity - firstly, the kind of traction (electric or diesel), secondly, the general kind of train (passenger, commuter or freight). Thus, more groups of fundamentally different trains were processed together.

The third parameter was the route of the train, including stopping regime. The fourth was mass and tractive forces of the train. The fifth was the train length and the last was the maximum speed.

The clustering algorithm included calculation of similarity ("distance") between two trains, which is the product of parameter-specific distances which comprise parameter-specific weights.

From each cluster, a sample train was formulated as follows: the most frequent route with the most common stopping regime along it, and the most frequent braking regime and percentage. Further, besides other things, maximum recovery margin (surcharge), speed of trainset and minimum number of wagons were chosen. In addition, .8 quantile of maximum speed, mass and length were chosen. The selected stopping regime (i.e. used overtaking tracks) and the train length should match together.

Woodburn [39] investigated variability in number of wagons in a freight train of particular category or origin-destination pair. His survey was based on a sample of almost 3,000 individual freight trains, with analysis at four levels of disaggregation, from the commodity groupings used in official statistics down to individual services. He identified considerable variability even at fairly high levels of disaggregation.

Šimral [40], as co-founder of freight railway undertaking METRANS Rail Ltd. and a locomotive driver himself, pointed out that some railway undertakings did not equip their trains with appropriate locomotives, so the PMR (power to hauled brutto mass ratio $[\mathrm{kW} / \mathrm{t}])$ of such trains was very low. Or the drivers were not motivated to keep allowed 
(and scheduled) speed. Thus, real runtimes were considerable higher than scheduled, and such trains could have delayed another ones. He proposed that keeping of scheduled speed should be legally enforced and that timetabling process in the Czech Republic should consider PMR as a priority factor by train path allocation.

Chýle [27] proposed sample freight trains with comparable high PMR (3.76 and 5.74) - combination of powerful modern locomotive and restricted brutto mass. Such sample trains enabled construction of PFTPs with relatively low capacity consumption.

\subsection{Aim and Principal Conclusions of the Article}

The main aim of this article is, on the basis of above cited research, to formulate a more detailed framework process for hierarchized construction of PFTPs. The process is more differentiated, distinguishing global (along the whole line) and local PFTPs, as well as bottleneck, other sections with dense traffic and remaining sections (with enough available capacity). The framework process considers fluctuations in demand for capacity from freight rail operators, so the quality of a PFTP is related with its construction priority. Thus, if the demand is low, PFTPs with higher quality can be offered to freight rail operators. Otherwise, the infrastructure manager has to decide according to his priority criteria.

The presented generic framework process aims to offer freight rail operators attractive PFTPs with as little number of stops as possible, and this way enhance competitiveness and decrease energy consumption of freight railway as a factor for sustainable development. The PFTPs are intended for all horizons of capacity allocation - from one or more years in advance to real-time dispatching. The framework process is virtually tested on the mainline Prague - Dresden, in the context of prospective (denser) passenger timetable.

The timetabling experiment (case study) has demonstrated correctness of the presented framework process, as well as its limits given by density and heterogeneity of passenger railway (the latter caused mainly by speed of long-distance trains and frequency of stops of regional trains).

\section{Materials and Methods}

\subsection{Materials Required for the Experiment}

For construction of periodic freight train paths (PFTPs) with the help of the method introduced below, following inputs are necessary:

- Track profile - number of tracks, stations with relevant tracks, speed and gradient profiles, block signals etc.;

- Model timetable of passenger transport - its periodic pattern including peak only services;

- Data indicating demand after PFTPs (at least past demand not older than 7 years).

For each pair of PFTPs (or group of more pairs of PFTPs), following sample train parameters are necessary as an input:

- Maximum allowed speed of the trainset (i.e. minimum of maximum allowed speeds of vehicles);

- Minimum power to hauled mass ratio (PMR) - relevant for the acceleration phase;

- $\quad$ Specific speed profile of the train (if relevant).

\subsection{Chosen Prospective Passenger Timetable and Railway Mainline}

For the timetabling experiment - railway capacity model with PFTPs, where the method introduced below was applied, such passenger timetable was chosen that was considered unsuitable for freight train paths for the following reasons: 
- $\quad$ Low period (30 min) of fastest (almost non-stop) trains;

- Suburban and regional trains with frequent stopping;

- Low arrival and departure headways between following fast and regional train (and vice versa) that mostly did not enable to schedule a freight train path between them.

The authors used timetable concept designed in diploma thesis of Rudolf Vávra $[41,42]$ - variant "Interposition". This timetable in the thesis, as well as the following timetabling experiment, were elaborated in FBS-iPLAN software [43] that the authors' faculty was licensed to use for academic purposes. The timetabling experiment was then elaborated on the basis of FPL graphic timetable files from Vávra's thesis, with kind permission of the author and in accordance with license of the thesis.

Table 1 shows frequencies of fast and regional segments of passenger transport (per section) in Vávra's thesis [41,42], compared to frequencies in real actual timetable [44]. The authors added for the purpose of the experiment a pair of hourly regional express trains between Prague and Kralupy, scheduled in interposition with fast trains.

Table 1. Numbers of passenger trains per hour and direction for actual and prospective timetables.

\begin{tabular}{ccccc}
\hline Section & \multicolumn{2}{c}{$\begin{array}{c}\text { Actual Timetable } \\
\mathbf{( 2 0 2 0 / 2 0 2 1 )}[44]\end{array}$} & Prospective Timetable [41,42] \\
\hline & Fast & Regional & Fast $^{2}$ & Regional \\
\hline Praha - Roztoky u Prahy ${ }^{2}$ & 2 & 4 & 4 & 4 \\
Roztoky u Prahy - Kralupy n. V. & 2 & 2 & 4 & 2 \\
Kralupy n. V. - Roudnice n. L. & 2 & 0.5 & 3 & 1 \\
Roudnice n. L. - Ústí nad Labem & 2 & 1 & 3 & 1 \\
Ústí nad Labem - Děčín $^{\text {Děčín - Schöna }}$ & 2.5 & 1 & 2.5 & 1 \\
Schöna - Pirna & 0.5 & 1 & 1 & 2 \\
Bad Schandau - Pirna & 0.5 & 1 & 1 & 2 \\
Pirna - Dresden & 0.5 & 2 & 1 & 0 \\
\hline
\end{tabular}

${ }^{1}$ From freight node station Praha-Libeň, passenger services occur gradually in three different stations or junctions. For the sake of simplicity, this fact is neglected (relevant sections are very short).

2 including hourly regional express services, scheduled by the authors.

Periodic arrival and departure times (minutes) are displayed in Figure 2, in the form of netgraph. It is the scheme of public transport lines, where the line style corresponds to service period. Here, a single full line stands for hourly service, and double full line stands for the $30 \mathrm{~min}$ service period. The time descriptors are on the side of travel direction from the edge - on the right. The descriptor closer to a node shows the arrival time, the one further from the node shows the departure time. 2-hour period is displayed by dashed line. Minutes at odd hours are written in italics. Intermediate stoppings are displayed on particular lines either as a single point, or as a number of stoppings in a circle - see Michl et al. [45] (pp. 29-30).

Based on the passenger timetable, railway line Praha-Libeň - Praha-Holešovice Ústí nad Labem - Děčín - Bad Schandau - Dresden Hauptbahnhof (Hbf, main station) was chosen. This mainline is important for passenger transport - long-distance connection of Prague with eastern and middle Germany, and with northern and western Bohemia. In addition, Bohemian-Saxon Switzerland is an important tourist attraction for both neighbouring countries. The mainline runs through Prague and Dresden agglomeration, and cities of Ústí nad Labem and Děčín, which are located closely together. Thus, suburban and regional transport are significant as well - majority of the mainline runs through catchment area of some city stated above [46].

There is considerable freight traffic on this mainline as well. International traffic is strong, and consists of various goods, for instance, but not only, of intermodal containers from German maritime ports and other terminals. Coal is another significant goods. It is 
mostly transported from North Bohemian Basin (westwards from Ústí nad Labem). The destinations are coal power plants - e.g. Mělník Power Plant, linked to Dolní Beřkovice and Hněvice stations on this mainline, or power plants eastwards from Prague. In northwestern Bohemia, there is located chemical industry as well, and the chemicals are transported by railway. Last group of goods are wagonload trains with mixed goods. Marshalling yards are situated in stations Praha-Libeň, Kralupy nad Vltavou, Hněvice, Lovosice, Ústí nad Labem západ (slightly aside the mainline, but within Ústí nad Labem node) and Děčín. The stations listed above mostly enable overtaking of $740 \mathrm{~m}$ long trains, as required by Article 39, Paragraph 2a of the Regulation (EU) No 1315/2013 [47]. However, maximum train length is restricted by Czech infrastructure manager Správa železnic to $658 \mathrm{~m}$ [48-50].

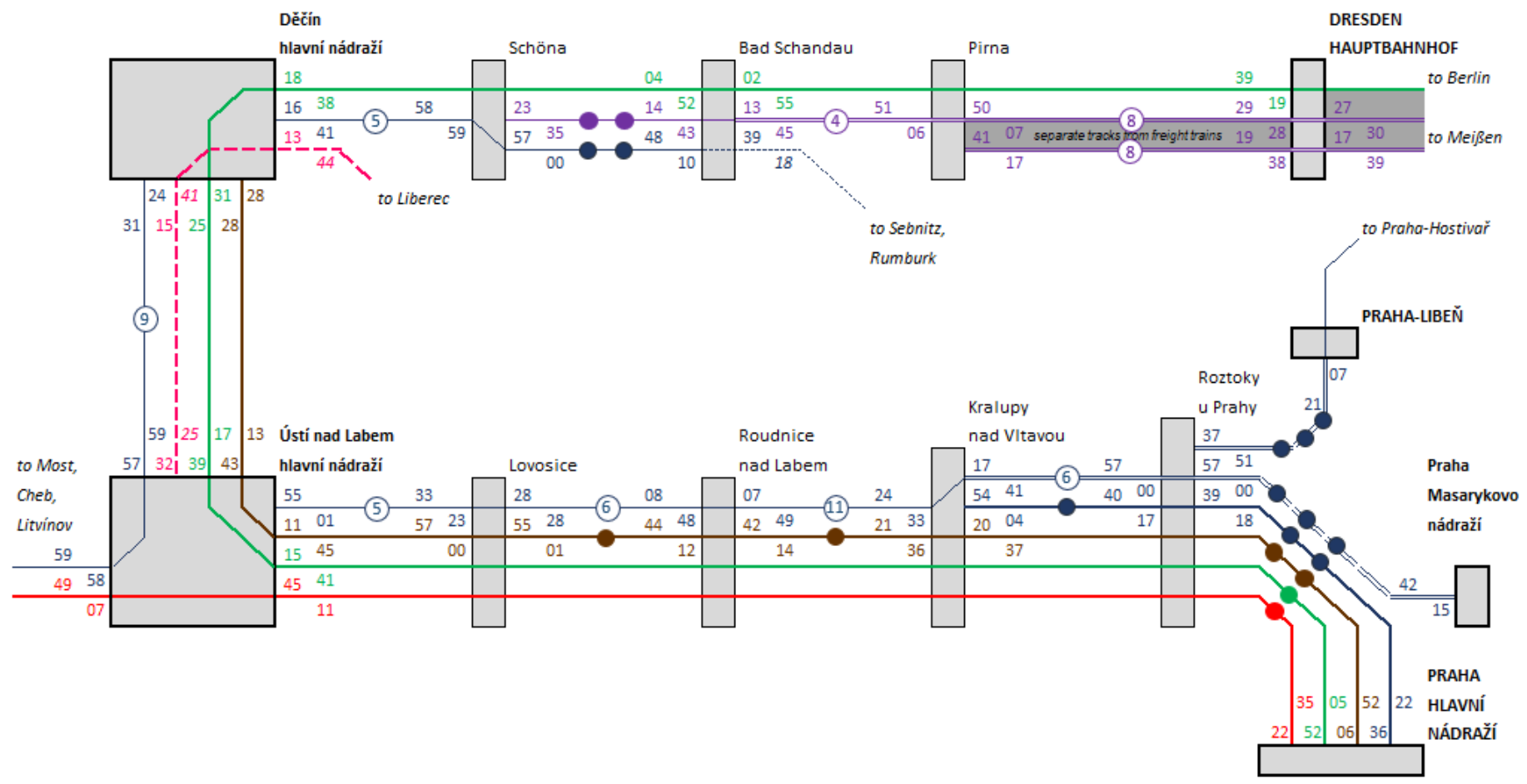

Figure 2. Netgraph of periodic passenger services. Source: authors. Data: [41].

\subsection{Freight Railway Transport Data}

Parameters of freight trains on the mainline Praha - Ústí n. L. were derived from analytical part of research project Optimization of Development of the Railway System of the Czech Republic in Terms of Transport Needs [51] (pp.118-121). Within this project, data on trains that really ran between March 2015 and 2016, gathered and provided to researchers by Správa železnic, were analysed with the help of hierarchical cluster analysis by Kříž. For each researched mainline, a representative section between neighbouring stations was chosen. For the mainline Praha - Ústí n. L., a section with the highest frequency of trains - between Praha-Bubeneč and Roztoky $u$ Prahy - was chosen.

Cluster analysis was elaborated on the basis of hauled brutto mass and total power of locomotives (both data sets were transformed to standard score). Ward's method clustering with Euclidean distance was chosen. Data of representative trains for each cluster, shown in Table 2, were determined as .8 quantile of values of particular parameter from particular cluster.

Table 2. Parameters of clusters of freight trains between Praha-Bubeneč and Roztoky u Prahy [51] (p. 121). ${ }^{3}$

\begin{tabular}{lllll}
\hline No. No. of Trains & Hauled Brutto & Power & PMR & No. of Trains by Max.
\end{tabular}




\begin{tabular}{cccccccc}
\hline & & Mass [t] & [kW] & {$[-]$} & \multicolumn{3}{c}{ Speed [km/h] } \\
\cline { 5 - 7 } & & & & & $\mathbf{9 0}$ & $\mathbf{1 0 0}$ & Other \\
\hline 1 & 865 & 1,685 & 6,000 & 3.56 & 31 & 830 & 4 \\
2 & 1,109 & 1,865 & 3,060 & 1.64 & 674 & 384 & 51 \\
3 & 708 & 705 & 3,060 & 4.34 & 324 & 267 & 117 \\
\hline
\end{tabular}

${ }^{3}$ Based on data on trains that really ran between March 2015 and March 2016, by Správa železnic [51] (p. 121).

Table 3 shows numbers of scheduled freight train paths (FTPs) in Czech railway timetable 2020/2021 [52]. The authors counted all regularly scheduled FTPs, except local (manipulation) freight trains and locomotive trains. For each section displayed in the table, maximum number of FTPs in one section between neighbouring stations (chosen for each direction separately) was considered.

For more accurate estimation of average freight demand for capacity during daytime, when passenger and freight trains have to share the capacity, following assumptions were made:

1. Daytime with considerable passenger traffic lasts 16 hours (e.g. 5:00 to 21:00);

2. Outside daytime, twice as many FTPs can be scheduled, compared to daytime.

Thus, average numbers of FTPs per section were divided by $(16+8 \times 2)$, i.e. 32 hours. This way, average hourly numbers of FTPs during daytime, per section and direction, were estimated.

Table 3. Numbers of scheduled regular freight train paths (FTPs) per section and daytime hour. Source: authors. Data:

[52]

\begin{tabular}{ccccc}
\hline Section & $\begin{array}{c}\text { Daily No. of } \\
\text { FTPs There }\end{array}$ & $\begin{array}{c}\text { Daily No of } \\
\text { FTPs. Back }\end{array}$ & $\begin{array}{c}\text { Average Daily } \\
\text { No. of FTPs }\end{array}$ & $\begin{array}{c}\text { No. of FTPs per day- } \\
\text { time hour }\end{array}$ \\
\hline Praha - Ústí nad Labem & 54 & 54 & 54 & 1.69 \\
Ústí nad Labem - Děčín & 50 & 39 & 45 & 1.41 \\
Děčín - Dresden & 107 & 116 & 112 & 3.5 \\
\hline
\end{tabular}

${ }^{4}$ Divided by 32.

Parameters of sample freight trains, displayed in Table 4, were, however, determined as looser (especially in terms of PMR) to enable more freight trains to use designed PFTPs.

For PFTPs that cover whole mainline between Prague and Dresden, comparably higher PMRs (between 2.2 and 2.5) were chosen, so that better quality of a PFTP - or, at least, higher acceleration after stop for an overtaking - can be ensured.

PFTPs between Prague and Ústí were, on the other hand, designed for trains with lower PMR (between circa 1 and 1.5) - coal or mixed (freight) trains.

Between Děčín-Prostřední Žleb, where "right-shore" mainline from Kolín, with busy freight traffic, connects to the researched mainline, PFTPs for various freight trains have to be considered. So, PMRs vary from circa 1.2 to 3.1 .

For the timetabling experiment, only electric locomotives were considered. However, freight trains with diesel locomotive(s) can use such PFTPs as well, given sufficient PMR.

Table 4. Parameters of sample freight trains for PFTPs. Source: authors.

\begin{tabular}{|c|c|c|c|c|c|c|c|c|}
\hline Catalogue PFTP & $41 x x x$ & $45 x x x$ & $44 x x x$ & $42 x x x$ & $46 x x x$ & $48 x x x$ & $65 x x x$ & $67 x x x$ \\
\hline Route & \multicolumn{3}{|c|}{ Praha - Dresden } & \multicolumn{3}{|c|}{ Děčín P. Ž. - Dresden } & $\begin{array}{l}\text { Praha - } \\
\text { Ústín. L. }\end{array}$ & $\begin{array}{l}\text { Ústín. n. L. } \\
\text { - Děčín }\end{array}$ \\
\hline I osomotive lase & DB & DB & ČDC & DB & ČDC & ČDC & ČDC & ČDC \\
\hline Locomotive class & 185 & 185 & 372 & 185 & 372 & 372 & 121 & 163 \\
\hline Power $[\mathrm{kW}]$ & 5,600 & $5,600^{1}$ & 3,080 & 5,600 & 3,080 & 3,080 & 2,032 & 3,060 \\
\hline
\end{tabular}




\begin{tabular}{ccccccccc} 
Hauled brutto mass [t] & 2,250 & 2,430 & 1,360 & 1,800 & 1,988 & 2,544 & 2,070 & 2,067 \\
PMR [-] & 2.49 & 2.30 & 2.26 & 3.11 & 1.55 & 1.21 & 0.98 & 1.48 \\
Length [m] & 514 & 554 & 262 & 415 & 358 & 466 & 380 & 382 \\
Maximum speed [km/h] & 100 & 100 & 100 & 100 & 90 & 90 & 90 & 90 \\
Braked weight percentage $^{\text {Prake regime }}{ }^{5}$ & 100 & 100 & 100 & 100 & 90 & 80 & 80 & 90 \\
Brake reaty $_{\text {Timetabling priority }}$ & $\mathrm{P}$ & $\mathrm{P}$ & $\mathrm{P}$ & $\mathrm{P}$ & $\mathrm{P}$ & $\mathrm{G}$ & $\mathrm{G}$ & $\mathrm{G}$ \\
\hline
\end{tabular}

${ }^{5} \mathrm{P}$ - passenger train braking, $\mathrm{G}$ - freight train braking

\subsection{Method of PFTPs Timetabling Experiment}

The introduced method for construction of symmetric PFTPs extends Drábek's framework process (Figure 1) and observes following generic principles:

1. Hierarchy of the offer of PFTPs and related hierarchy of the construction process;

2. Segmentation of the solved mainline (or network) into:

- Bottlenecks;

- $\quad$ Other busy sections (with dense traffic);

- $\quad$ Rest of the line/network.

3. Speed bundling whenever it saves capacity and does not lead to unnecessary extra overtaking or waiting;

4. Active overtaking of or by a passenger train for the express PFTPs.

5. Scheduling of overtaking for subsequent PFTPs in various stations, so the capacity is utilized efficiently (the acceleration of a freight train is the most capacity-consuming phase of its running) [34] (p. 28).

As the $2^{\text {nd }}$ edition of UIC Codex 406 [19] (pp.30-31) implies, increase of capacity utilization leads to decrease of train path quality, and vice versa. The authors assume high daily fluctuations in utilization of PFTPs by freight trains. Thus, they propose to offer reserves in hourly capacity (compare Tables 3 and 4) and segmentation of global (international) PFTPs in terms of quality - express, fast and "common" with more overtakings. In many cases, only the best global PFTP would be used. Then, the second one can be, if need be, used for a domestic freight train, qiven sufficient PMR and speed. The third one would be used only if the first two ones cannot satisfy the freight operators' demand for capacity in particular day, hour and direction.

The priority criteria for generic framework process for hierarchical construction of PFTPs are arranged in descending order as displayed in Figure 3.

In some special cases, lost capacity in the sense of the $1^{\text {st }}$ edition of UIC 406 Codex [17] (p. 16) can be utilized by active overtaking, i.e. without stopping of the overtaken train. This train is scheduled to an opposite track, given that it is not occupated by traffic in the opposite direction. Because of comparably high train frequency on the mainline, only a section between neighbouring stations can be used for this purpose. While constructing PFTPs this way, one has to pay attention whether another potential good PFTP is not avoided (see Figure 4). Given PFTPs in both directions are constructed in a symmetric way, the mentioned active overtaking has to be scheduled symmetrically in both directions as well. Thus, occupation of the opposite track is fundamentally impossible in the minutes 00 and 30, or 15 and 45 in addition, and few minutes before and after these times. The exact width of "forbidden timespan" depends on particular section and occupation time of the opposite track by the overtaken train. 


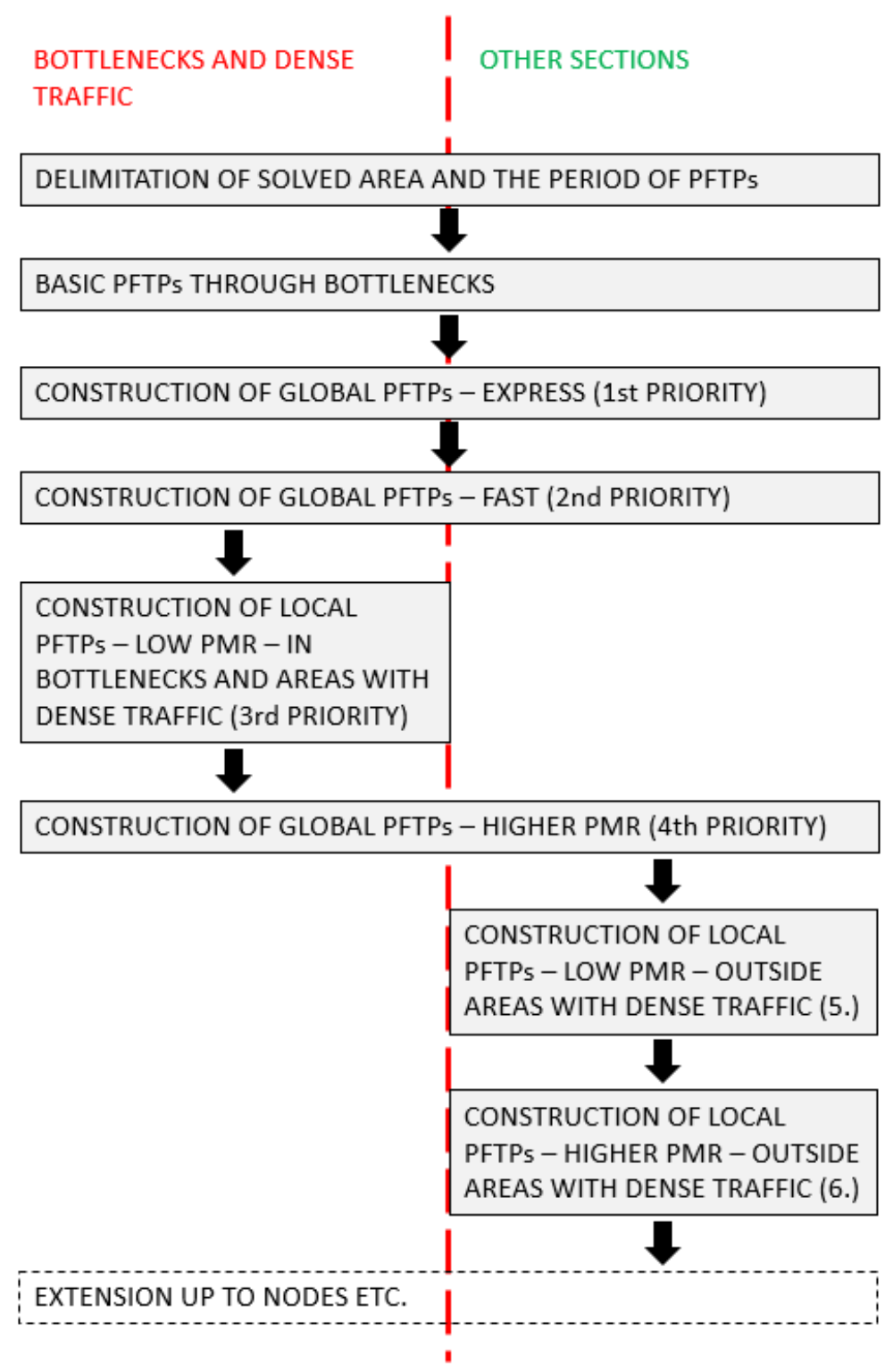

Figure 3. Proposed generic framework process for hierarchical construction of PFTPs. Source: authors. 


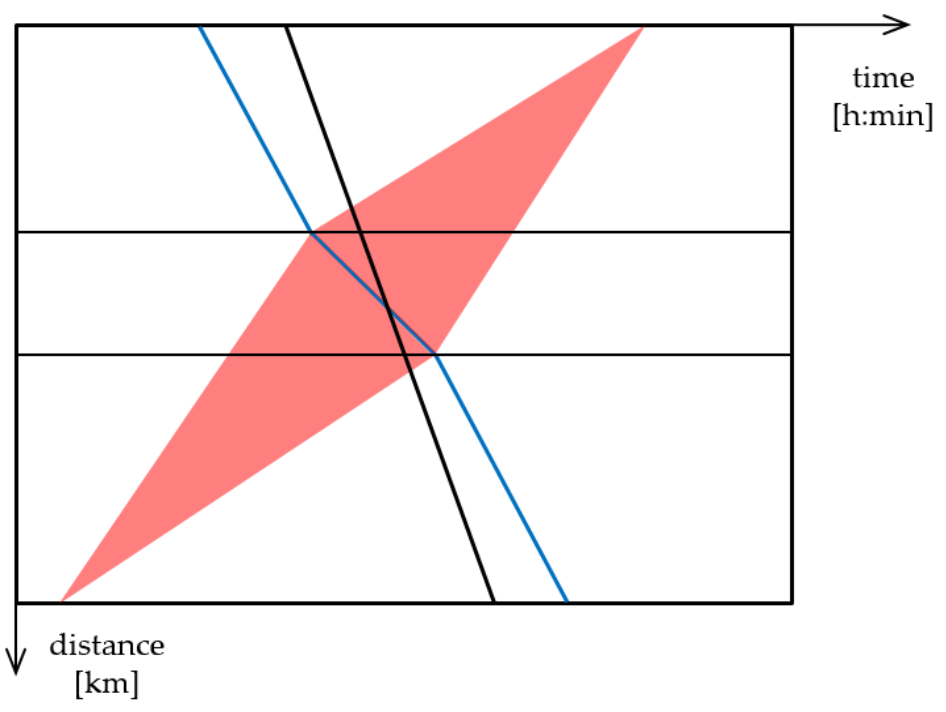

Figure 4. Illustration of unusable capacity for the opposite direction (for not stopping trains). A PFTP is displayed in blue colour. Source: authors.

Freight trains with extremely low PMR, speed, or extremely long ones are supposed to be scheduled either in freight off-peak hours, provided that one such train can run without disturbing neither passenger nor "standard" freight trains, or at night, after scheduling of "standard" freight trains.

The construction of all relevant PFTPs ends either when the expected peak demand can be reasonably satisfied or when usable capacity is exhausted. As a rule of thumb, if there is necessary to schedule overtaking in more than $33 \%$ of the stations on the railway line, the quality of PFTP is very low, it should not be scheduled unless justified by sufficient expected demand. The standard recovery margin for PFTPs is $10 \%$ of the calculated theoretical runtime.

The output of this method is a coordinated periodic timetable pattern of passenger and freight train paths with unified symmetry that can be extended into all-day exact timetable (with some minor adjustments - passenger off-/peak times etc.). PFTPs should be offered to the railway undertakings in following descending priority order:

1. Pre-arranged paths (PaPs) for European Rail Freight Corridors (as defined by Regulation No. 913/2010 [53]) if relevant;

2. Annual timetable (e.g. combined transport);

3. Ad hoc regime (few days before actual running of the train);

4. Dispatching (delay or another irregularity).

\section{Results}

The timetable experiment has resulted in scheduling of eight pairs of hourly PFTP pairs with unified symmetry (for parameters, see Table 4.). Three pairs proceeded during the whole solved mainline, three pairs between Děčín-Prostřední Žleb ("right-shore" mainline) and one between Prague and Ústí, and between Ústí and Děčín (both for trains with low PMR). Netgraph with periodic passenger and freight train paths is displayed in Figure 5. Recovery margins (surcharges) per section and direction are displayed in Table 5. Resulting graphical timetable (train diagram) is attached as supplementary material - Figure S1.

It is evident that more passenger (and freight) train paths per hour cannot enable lower average number of overtakings for one freight train path. However, all PFTPs are supposed to be utilized only in absolute peaks of freight operators', which is few days in a month, and only for some hours during such a day. Average numbers of stops 
per freight train path in 2020/2021 timetable [52] and in the presented experiment are compared in Table 6.

The above stated numbers of scheduled stoppings would have been higher, if extensive "bending" (artificial runtime lengthening) of PFTPs had not been implemented. Such "bending" is evident from Table 5 - see the recovery margins over $10 \%$. The first section, where all PFTPs (except 65xxx with comparably low PMR) had to be bent, is from Prague node to Kralupy. The reason was homogenization of train paths with frequently stopping suburban passenger trains (otherwise there would have been lack of railway capacity).

Between Kralupy and Ústí, bundled PFTPs 41xxx and 45xxx were slightly bent for enabling necessary synchronization runtime of 41xxx - between two active overtakings. During the first one (between Nelahozeves and Vraňany), 41xxx was even more bent to have enough long sectional runtime to be overtaken by nonstop fast train to Cheb. On the other hand, standard recovery margin of 41xxx was reduced between Ústí and Povrly to enable overtaking of a frequently stopping passenger train. The above described solution is functionally symmetrical for both directions (and difference between recovery margins in direction there and back is comparably low).

For the pair of PFTPs 65xxx, no bending in any direction was implemented. On the contrary - the standard recovery margin had to be reduced from Hněvice to Ústí and from Ústí to Nelahozeves, otherwise there would have been necessary more overtakings. The pair of short PFTPs 67xxx had standard recovery margin in both directions.

The timetabling experiment has demonstrated that high level of extermal unified symmetry of PFTP could be maintained. The only exception is a pair of PFTPs 65xxx with low PMR, scheduled between Prague and Ústí. From Prague, most probably thanks to ride down the stream of Vltava and Labe rivers, only two overtakings took place. On the other hand, there were four overtakings between Ústí and Prague. This discrepancy has influenced asymmetric arrival and departure time from/to direction Ústí nad Labem západ node station (in the junction Ústí nad Labem jih next to Ústí main station).

For all other PFTPs, external unified symmetry was maintained. For almost all of them, internal unified symmetry was maintained as well. The only exception was a pair of PFTPs No. 42xxx between Děčín-Prostřední Žleb and Dresden. As a pair of PFTPs (for given distance) with the lowest PMR, it was chosen to be stopped in Děčín-Prostřední Žleb in the direction Děčín východ (and in Bad Schandau Ost in the opposite direction) for the purpose of synchronization with free symmetric time slots on the single-track section between the stations Děčín-Prostřední Žleb and Děčín východ.

For practical reasons (actual passenger timetable - see Figure 2), the timetable symmetry axis of PFTPs was not the minute zero, but the minute circa 56 to 58 .

The proposed catalogue PFTPs can be used by freight operators in different ways, depending on actual capacity utilization on particular day and at particular hour. The default case is that each PFTP is used by a train with corresponding parameters.

When at least one PFTP at particular hour and direction is not used, some changes in ad-hoc (daily) timetabling or train dispatching are possible. For example, a suitable train with shorter route can be scheduled in a part of this PFTP. Or, if the particular trains has parameters suitable for both particular PFTPs, an additional stop can be scheduled, and the train can use both PFTPs partially.

If more PFTPs remain free, the best one (in terms of number of scheduled stops) can be allocated for the train - given sufficient parameters to fit into it. 


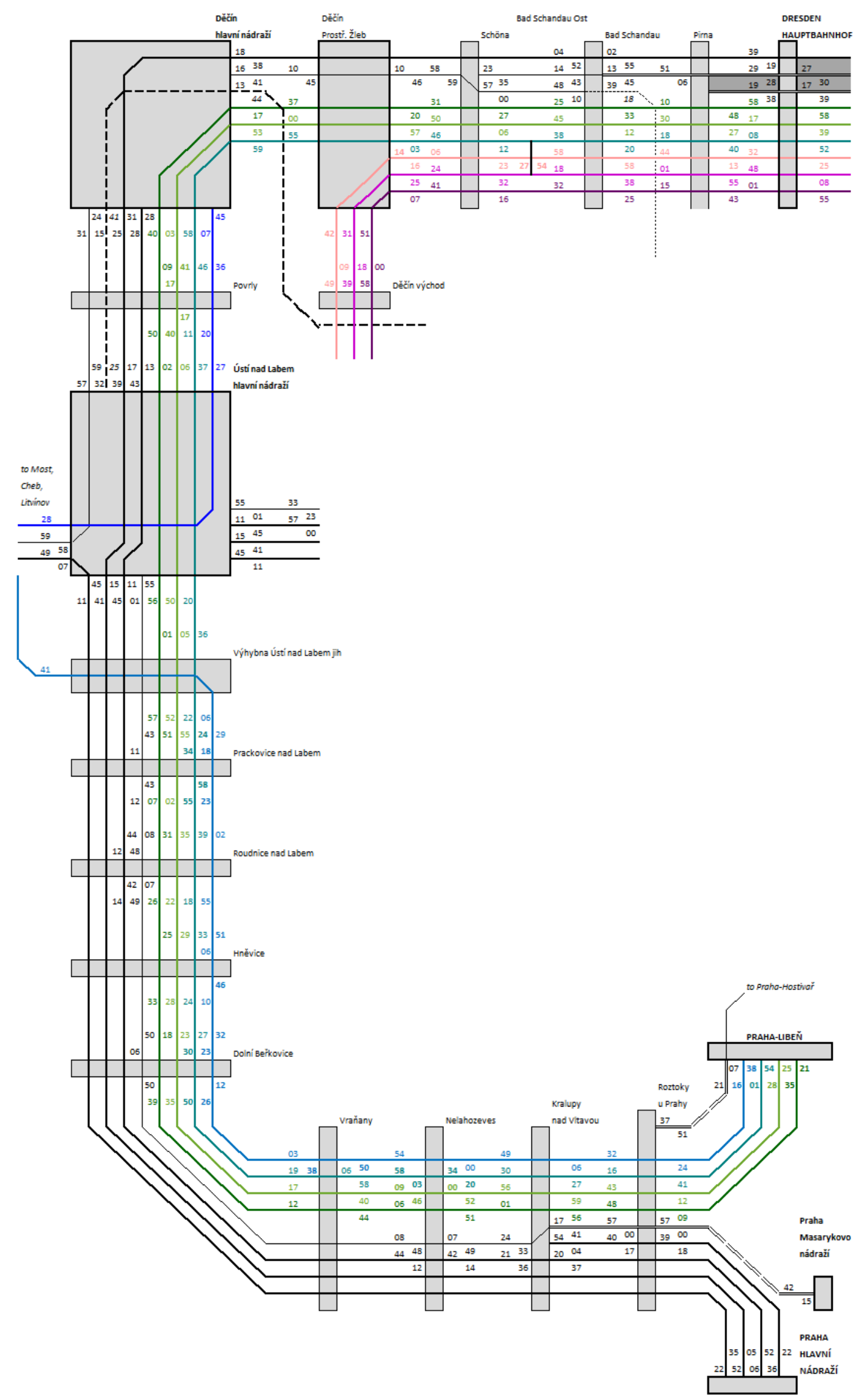

Figure 5. Netgraph of periodic passenger services (data: [41]) and resulting PFTPs. Source: authors. 
Table 5. Recovery margins (displayed as a percentage of minimum runtime, as an input for runtime calculation by FBS software) for particular PFTPs and sections (direction there/back). Bold numbers indicate sections with active overtaking.

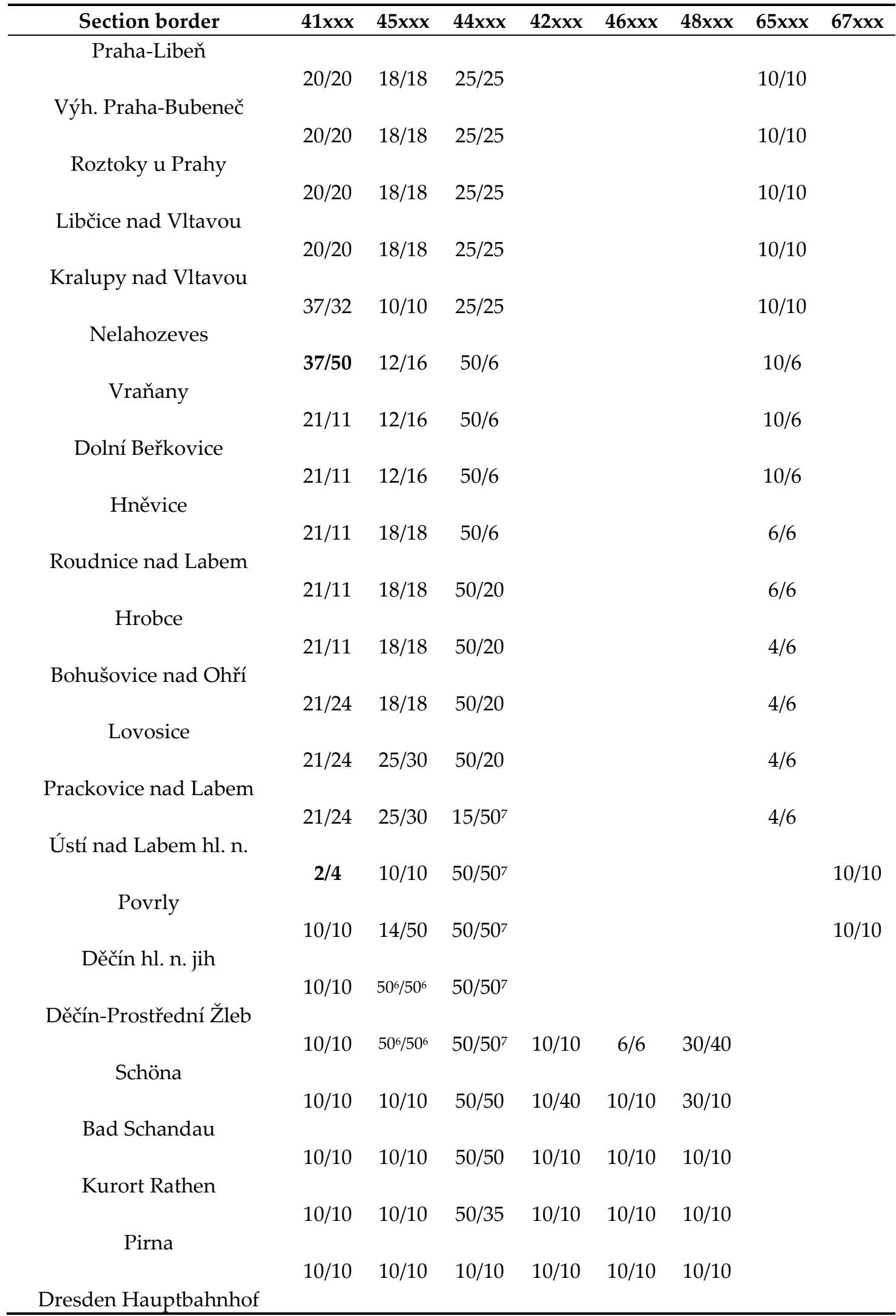

${ }^{6}$ Additional $5 \%$ mass margin (surcharge), as an input for calculation by FBS software.

${ }^{7}$ Additional $20 \%$ mass margin (surcharge), as an input for calculation by FBS software.

Table 6. Comparison of absolute and relative numbers of scheduled stops [48-50,52]. Source: authors. 


\begin{tabular}{ccccccc}
\hline \multirow{2}{*}{ Section } & \multicolumn{3}{c}{ Timetable 2020/2021 [52] (Daily) } & \multicolumn{2}{c}{ Timetabling experiment (Hourly) } \\
\cline { 2 - 7 } & There & Back & $\begin{array}{c}\text { No of Stops per } \\
\text { Train Path }\end{array}$ & There & Back & $\begin{array}{c}\text { No of Stops per } \\
\text { Train Path }\end{array}$ \\
\hline Praha - Ústí nad Labem & 33 & 31 & 0.59 & 6 & 8 & 1.75 \\
Ústí nad Labem - Děč́n & 45 & 45 & 1.01 & 1 & 1 & 0.25 \\
Děčín - Dresden & 5 & 13 & 0.08 & 1 & 1 & 0.17 \\
\hline
\end{tabular}

${ }^{8}$ Length limit defined by Správa železnic [48-50].

${ }^{9}$ Length limit is likely further limited by adjoining "right-shore" mainline.

Table 7 shows maximum length of a freight train, including locomotive(s). It was calculated from the usable length of the shortest station track scheduled for overtaking for particular PFTP. From this length (between departure signals in opposite directions as a rule [52]), $20 \mathrm{~m}$ was subtracted to ensure visibility of the signal from the driver's cab and to ensure smooth arrival and stopping of a freight train on the track.

For some PFTPs that are not scheduled to stop (41xxx, 46xxx and 48xxx), the only limit for length of a train is defined by the infrastructure manager - Správa železnic [48-50].

Table 7. Maximum length of a train for particular PFTP and direction $[\mathrm{m}]$ and scheduled numbers of intermediate stops.

Data: [48-50,52]. Source: authors.

\begin{tabular}{|c|c|c|c|c|}
\hline PFTP & There (to Dresden) & Back (to Prague) & Stops There & Stops Back \\
\hline $41 x x x$ & $658^{8}$ & $658^{8}$ & 0 & 0 \\
\hline $45 x \times x$ & 635 & 630 & 2 & 2 \\
\hline $44 x x x$ & 635 & 627 & 3 & 3 \\
\hline $42 x x x$ & 580 & 666 & 1 & 1 \\
\hline $46 x x x$ & $695^{8,9}$ & $695^{8,9}$ & 0 & 0 \\
\hline $48 x x x$ & $695^{8,9}$ & $695^{8,9}$ & 0 & 0 \\
\hline $65 x x x$ & 615 & 593 & 2 & 4 \\
\hline $67 x x x$ & $695^{8}$ & $695^{8}$ & 0 & 0 \\
\hline
\end{tabular}

\section{Discussion}

\subsection{Interpretation in the Context of Previous Studies}

The presented framework process makes Drábek's approach from his doctoral thesis [32] more accurate in terms of capacity offer for various freight services and related hierarchy of the train path construction process. The PFTPs are constructed in suitable time windows (as recommended by Lindner and von Redern [11]), with maintained unified symmetry axis for both directions. Outside bottlenecks (Prague - Kralupy in the study) and other busy sections (Kralupy - Ústí in the study), flexibility in freight train stopping (as referred to by Opitz [9] and Vromans [14]) is possible, provided that not all PFTPs are allocated for particular time and direction, and the freight train fulfils the limits of all utilized PFTPs. The presented approach proposes to locally homogenize PFTPs in bottlenecks and other busy sections as much as possible. For the express PFTPs (41xxx in the study) the approach proposes to implement active overtaking in suitable section and time, as proposed by Janoš and Kříž [29]. The presented approach is holistic and this way brings new quality into scheduling and allocation of periodic (pre-arranged) freight capacity.

\subsection{Discussion of the Proposed Approach and Resulting Timetable}


All PFTPs were scheduled to stop in Praha-Libeň marshalling yard. There is a busy triple-track mainline, which proceeds eastwards. There is also a single-track freight bypass line which leads further southwards or westwards. However, this line crosses the busy mainline without a flyover. Thus, before there will be built a double-track flyover, the capacity is very low. This is the main limitation of the proposed concept of PFTPs.

The resulting symmetrical timetable of hourly PFTPs evinces strong variedness, depending on section of the solved mainline. From Prague to Kralupy, a bottleneck full of mixed passenger traffic forces PFTPs to be strictly parallel and bundled by two. So, the PFTP 65xxx with the lowest PMR determines the "gradient angle" of all PFTPs in both directions. Other PFTPs in the bottleneck have to be slowed accordingly, otherwise the train path heterogeneity would increase, and, as a result, capacity would decrease.

From Kralupy to Ústí, there is an "zone of overtaking", which is caused by high train path heterogeneity (from regional trains with low average speed, through PFTPs, to non-stop long-distance trains in $30 \mathrm{~min}$ period, running up to $160 \mathrm{~km} / \mathrm{h}$ in the middle of this section). The "tight" periodic pattern of passenger timetable, where regional trains are overtaken as well, and no time windows remain for the freight trains to run through without a stop, further deteriorates the train path quality. Such passenger timetable pattern was intentionally chosen to demonstrate limits of freight timetabling. The resulting PFTPs show clearly that this aim was achieved. Without scheduling of active overtakings in two sections, no non-stop PFTP could have been designed within this passenger timetable.

The section between Ústí and Děčín nodes is very short. It contains only one intermediate station between these nodes - Povrly. There is only one pair of overtakings PFTP 45xxx. The overtaking here represents synchronization of two advantageous time windows - from Prague and short overtaking in Nelahozeves by non-stop passenger train, which actively overtakes PFTP 41xxx, to narrow time window between ending regional and beginning suburban trains in Bad Schandau - and vice versa in the opposite direction.

The section from Děčín to Pirna is tricky - number of passenger trains is comparably low, but the regional ones stop very frequently - especially between Děčín and Bad Schandau. Resulting low average speed leads to necessity of intensive "bending" of PFTPs (44xxx and 45xxx) to avoid further scheduled stops - see Table 5. To a lesser degree, this constraint proceeds to Pirna, where suburban trains enter a separate parallel double-track line.

From Pirna to Dresden Hbf, PFTPs are limited only by hourly EuroCity trains (which run faster, but the section is short) and mutual coordination.

Further from Dresden $\mathrm{Hbf}$ freight trains enter a separate double-track line, up to marshalling yard Dresden-Friedrichstadt.

\subsection{Recommendation for Further Research}

The presented timetabling experiment, as well as similar experiments in Drábek's doctoral thesis [32] have shown that some particular sections (or, more broadly, some sections between two overtakings) are limiting parameters of a freight train - PMR, given some minimum recovery margin (surcharge, buffer time) to technical (theoretical) runtime, and maximum length of the train, depending on the shortest utilized overtaking track. A similar symmetric periodic timetable, coordinated for both passenger and freight trains, with more balanced distribution of such limitations would enable increase of freight railway transport capacity, without costly construction. However, it is necessary to formulate a suitable mathematical approach, whose application would not deteriorate other criteria, relevant for the timetable.

Another persisting problem, with overlap to jurisprudence, that does not have impact only on freight, but also on passenger railway as well, is excessive frequency of stopping of suburban and regional trains, which is in many cases not justified by sufficient passenger demand. So, the settlements that generate the least demand, can be 
in most cases served by bus instead. The problem consists in penalization of small group of inhabitants (in terms of longer travel time and/or extra transfer), for the sake of increase of mainline capacity (by decrease of train path heterogeneity in the sense of $1^{\text {st }}$ edition of UIC 406 Codex [19]).

Gradual realization of parallel high-speed railway lines will on the one hand relieve the conventional mainlines from majority of long-distance passenger trains - on the other hand, there will occur new dimension of complexity of the network timetabling process. Due to anticipated increase in total passenger traffic, new bottlenecks are likely to occur, especially in agglomeration node areas, such as Prague or Ústí nad Labem. For the freight railway, higher capacity outside bottlenecks will be counterweighted by necessity of more accurate scheduling (and real-time dispatching) through major bottlenecks. These problems will likely further emphasize the network-oriented and multicriterial aspects of the railway operation research.

\section{Conclusions}

The resulting line periodic timetable has clearly shown that freight railway suffers not directly from frequency of passenger trains, but from their high heterogeneity in terms of average speed. Regional train paths are obviously considerably more heterogeneous to PFTPs than the long-distance ones. Keeping present frequency of long-distance offer is not advisable, as long-distance train ridership has been growing [54] (p. 33). Thus, the only sustainable solution is restriction of regional train stopping in the stops with low passenger demand. Since this measure is extremely politically sensitive, following measure is recommended - regional trains should serve such stops only in 2-hour period as nowadays. The saved time windows should be scheduled so that at least some PFTPs can be scheduled with one less stopping. The peak times, in reasonable timespans, should make an exception, which lowers PFTP quality to the proposed timetable.

The presented approach enabling the composition of passenger train paths in IPT and PTFPs could serve as a basic input methodology for capacity analyzes, which are necessary for increasing the share of rail freight transport on the transport market and for the whole concept of sustainable freight transport.

Supplementary Materials: The following are available online at www.mdpi.com/link, Figure S1: Timetable Praha-Libeň - Dresden Hauptbahnhof in A3 size.,

Author Contributions: Conceptualization, M.D. and V.J.; methodology, M.D.; software, V.J.; validation, V.J. and M.D.; formal analysis, V.J.; investigation, M.D.; resources, V.J.; data curation, M.D.; writing - original draft preparation, M.D.; writing - review and editing, V.J.; visualization, M.D.; supervision, V.J.; project administration, M.D.; funding acquisition, V.J. All authors have read and agreed to the published version of the manuscript.

Funding: This research received no external funding.

Data Availability Statement: Data sharing not applicable.

Acknowledgments: Publishing of this paper in open access was supported by Czech Technical University in Prague. The authors hereby acknowledge the funding sponsor.

Conflicts of Interest: The authors declare no conflict of interest.

\section{References}

1. United

Sustainable

Development

Goals. Available

online: https://www.un.org/sustainabledevelopment/sustainable-development-goals/ (accessed on 7 April 2021).

2. United Nations General Assembly. Resolution Adopted by the General Assembly on 25 September 2015. 70/1. Transforming Our World: the 2030 Agenda for Sustainable Development, 2nd ed United Nations General Assembly: New York, USA, $2015 ;$ p. 14. Available online: https://undocs.org/A/RES/70/1 (accessed on 7 April 2021).

3. European Commission. 3.2.5. GHG Emissions from Transport EU-27 - by Mode (shares \%). In EU Transport in Figures - Statistical Pocketbook 2020; Publications Office of the European Union: Luxembourg, Luxembourg, 2020; p. 137, ISBN 978-92-76-17565-0, ISSN 2363-2739, Available online: https://doi.org/10.2832/491038 (accessed on 7 April 2021). 
4. European Commission: European Commission: Communication from the Commission to the European Parliament, the European Council, the Council, the European Economic and Social Committee and the Committee of the Regions. The European Green Deal. COM/2019/640 Final; Brussels, Belgium, 2019; Available online: https://eur-lex.europa.eu/legal-content/EN/TXT/?uri=COM\%3A2019\%3A640\%3AFIN (accessed on 7 April 2021).

5. European Commission: Proposal for a Regulation of the European Parliament and of the Council Establishing the Framework for Achieving Climate Neutrality and Amending Regulation (EU) 2018/1999 (European Climate Law). COM/2020/80 Final; European Commission: $\quad$ Brussels, Belgium, 2020; Available online: https://eur-lex.europa.eu/legal-content/EN/TXT/?qid=1588581905912\&uri=CELEX:52020PC0080 (accessed on 7 April 2021).

6. Forschungsgesellschaft für Straßen- und Verkehrswesen, e. V. Merkblatt zum Integralen Taktfahrplan; FGSV-Verlag GmbH: Cologne, Germany, 2001; pp. 18-20.

7. Serafini, P.; Ukovich, W. A Mathematical Model for Periodic Scheduling Problems. SIAM J. Disc. Math. 1989, 2 (4), pp. 550-581, DOI: $10.1137 / 0402049$.

8. Liebchen, C. Periodic Timetable Optimization in Public Transport. Doctoral Thesis, Technische Universität Berlin, Berlin, Germany, 22 March 2006.

9. Opitz, J. Automatische Erzeugung und Optimierung von Taktfahrplänen in Schienenverkehrsnetzen. Doctoral Thesis, Technische Universität Dresden, Dresden, Germany, 2009, pp. 95-121. ISBN 978-3-8349-8466-1.

10. Müller, A. Möglichkeiten eines Cargo-Takt-Systems zur Verbesserung der Transportqualität im Schienengüterverkehr. Doctoral Thesis, RWTH Aachen, Aachen, Germany, 9 July 1999, pp. 11-13, 113-119.

11. Lindner, H.-R.; von Redern, H. W. Güterzüge im Taktfahrplan - Möglichkeiten und Grenzen. Die Bundesbahn 1989, 10, pp. 867-874.

12. Caimi, G.; Laumanns, M.; Schüpbach, K.; Wörner, S.; Fuchsberger, M. The Periodic Service Intention as a Conceptual Frame for Generating Timetables with Partial Periodicity. Transportation Planning and Technology 2011, 4, pp. 323-339, DOI: 10.1080/03081060.2011.577151.

13. Pöhle, D. Strategische Planung und Optimierung der Kapazität in Eisenbahnnetzen unter Nutzung von automatischer Taktfahrplanung. Doctoral Thesis, Technische Universität Dresden, Dresden, Germany, 22 March 2016, p. 193. ISBN 978-3-95935-322-9.

14. Vromans, M. Reliability of Railway Systems. Doctoral Thesis, Erasmus University Rotterdam, Rotterdam, Netherlands, 6 July 2005, pp. 84, 186. ISBN 90-5892-089-5.

15. Čapek, K. FlexFahrplan - A New Approach to Railway Operational Planning. Diploma Thesis, Czech Technical University in Prague, Prague, Czech Republic, 2004.

16. Klabes, S. G. Algorithmic Railway Capacity Allocation in a Competitive European Railway Market. Doctoral Thesis, RWTH Aachen, Aachen, Germany, 14 January 2010, p. 78.

17. International Union of Railways (UIC). UIC Code 406. Capacity, $1^{\text {st }}$ ed.; UIC: Paris, France, June 2004, pp. 3,16; ISBN 2-7461-0802-X.

18. Stoilova, S.; Munier, N.; Kendra, M.; Skrúcaný, T. Multi-Criteria Evaluation of Railway Network Performance in Countries of the TEN-T Orient-East Med Corridor. In Sustainability 2020, 12, p. 1482, DOI: 10.3390/su12041482, Available online: https://doi.org/10.3390/su12041482 (accessed on 23 March 2021).

19. International Union of Railways (UIC). UIC Code 406. Capacity, $2^{\text {nd }}$ ed.; UIC: Paris, France, June 2013; pp. 30-34. ISBN 978-2-7461-2159-1.

20. Gašparík, J., Čechovič, L., Blaho, P., Pečený, L. Capacity of Corridor Lines After Modernization. In Transportation Research Procedia 2021, 53, pp. 159-166, ISSN 2352-1465,

DOI: 10.1016/j.trpro.2021.02.021, Available online: https://doi.org/10.1016/j.trpro.2021.02.021 (accessed on 23 March 2021).

21. Čamaj, J. et al. The Planning of Investment Activities in Field of Railway Transport with Support of Simulation Tools. Transp. Res. Proc. 2021, 53, pp. 39-49, DOI: 10.1016/j.trpro.2021.02.005, Available online: https://doi.org/10.1016/j.trpro.2021.02.005 (accessed on 23 March 2021).

22. Bablinski, K. A game-based analysis of freight paths allocation with a case study on Great Britain Brighton Main Line. Transportation Research Procedia 2016, 13, pp. 196-208, DOI: 10.1016/j.trpro.2016.05.020, Available online: https://core.ac.uk/download/pdf/82597936.pdf (accessed on 23 March 2021).

23. Cacchiani, V., Caprara, A., Toth, P. Scheduling Extra Freight Trains on Railway Networks. Transportation Research Part B: Methodological 2010, 44 (2), pp. 215-231, DOI: 10.1016/j.trb.2009.07.007, Available online: https://doi.org/10.1016/j.trb.2009.07.007 (accessed on 23 March 2021).

24. Ljunggren, et al. Railway timetabling: a maximum bottleneck path algorithm for finding an additional train path. Available online: https://www.diva-portal.org/smash/get/diva2:1474704/FULLTEXT01.pdf (accessed on 23 March 2021).

25. Haldeman, L. Automatische Analyse von IST-Fahrplänen. Master Thesis, ETH Zürich, Zürich, Switzerland, 2005.

26. Růžička, J. Návrh postrkové služby v oblasti Vysočiny. Bachelor Thesis, Czech Technical University in Prague, Prague, Czech Republic, 12 September 2018. Available online: https://dspace.cvut.cz/handle/10467/8018 (accessed on 23 March 2021).

27. Chýle, M. Katalogové trasy pro nákladní vlaky na IV. tranzitním železničním koridoru. Diploma Thesis, Czech Technical University in Prague, Prague, Czech Republic, 17 May 2021. Unpublished. To be defended in June 2021.

28. Růžička, J. Katalogové trasy ve smíšeném provozu. Diploma Thesis, Czech Technical University in Prague, Prague, Czech Republic, 16 January 2021. Available online: https://dspace.cvut.cz/handle/10467/92608 (accessed on 23 March 2021). 
29. Janoš, V.; Kř́žž, M. Infrastructure Parameters Affecting Capacity of Railways in TEN-T. In Acta polytechnica CTU Proceedings; Jírová, J., Řezníčková, J., Eds.; Česká technika - nakladatelství ČVUT: Prague, Czech Republic, 2016; Volume 5, pp. 22-25. ISSN 2336-5382. ISBN 978-80-01-06022-3, DOI: 10.14311/APP.2016.5.0022, Available online: https://doi.org/10.14311/APP.2016.5.0022 (accessed on 23 March 2021).

30. Kamenický, D. Traffic Management System in Terms of Data Exchange. In Acta polytechnica CTU Proceedings; Jírová, J., Ǩezníčková, J., Eds.; Česká technika - nakladatelství ČVUT: Prague, Czech Republic, 2016; Volume 5, pp. 26-28, DOI: 10.14311/APP.2016.5.0026, Available online: https://doi.org/10.14311/APP.2016.5.0026 (accessed on 23 March 2021).

31. Drábek, M. Systematické katalogové trasy pro nákladní vlaky. In Proceedings of the EURO - Žel 2009, Žilina, Slovakia, 3-4 June 2009; Nagy P., Ed.; University of Žilina: Žilina, Slovakia, 2009; Vol. 2, pp. 141-148. ISBN 978-80-554-0024-2.

32. Drábek, M. Periodic Freight Train Paths in Network. Doctoral Thesis, Czech Technical University in Prague, Prague, Czech Republic, 6 June 2014. Available online: https://takt.fd.cvut.cz/cargo/Drabek thesis.pdf. (accessed on 22 March 2021).

33. Drábek, M. Network-bound Periodic Freight Train Paths - A Qualitative Generic Approach for Railway Capacity Management. In Proceedings of 4th International Seminar on Railway Operations Modelling and Analysis RailRome2011, Rome, Italy, 16-18 February 2011; Universita La Sapienza: Rome, Italy, 2011; pp. 1-17. ISSN 2211-453X.

34. Michl, Z. et al. Optimalizace využití tratí s vyčerpanou kapacitou. Methodology certified by Ministry of Transport. Czech Technical University in Prague, Prague, Czech Republic, 2016; pp. 26-31. Unpublished.

35. Drábek, M. On Symmetry of Periodic Freight Train Paths in Network. In Proceedings of Horizons of Railway Transport 2013, Strečno, Slovakia, 26-27 September 2013; University of Žilina: Žilina, Slovakia, 2013; pp. 120-128. ISBN 978-80-554-0764-7.

36. Kopecký, F., et al. Redakčně upravená závěrečná zpráva projektu CG723-138-190 - Konfigurace taktových uzlů v železniční síti ČR. Research Project for Czech Ministry of Transport. Unpublished. Prague, Czech Republic, January 2009.

37. Drábek, M. 6000 t zboží skrz Prahu. Každou hodinu. In Sborník př́spěvkư; LOGI 2009, Pardubice, Czech Republic, 19 November 2009; Kampf R., Ed.; University of Pardubice: Pardubice, Czech Republic, 2009; Volume 1, pp. 64-71, ISBN 978-80-7399-893-6.

38. Kuckelberg, A.; Gepper, A.; Janecek, D. Pattern Train Extraction for Analytical Railway Operations research. In Proceedings of the EURO - ZEL 2015, Žilina, Slovakia, 2-3 June 2015; Krištofová, L., Fabian P., Eds.; University of Žilina and Tribun EU: Žilina, Slovakia, 2015; Vol. 2, pp. 58-65. ISBN 978-80-263-0936-9.

39. Woodburn, A. An Empirical Study of the Variability in the Composition of British Freight Trains. J. Rail Transp. Plan. Manag. 2015, 5 (4), pp. 294-308, DOI: 10.1016/j.jrtpm.2015.12.001, Available online: https://doi.org/10.1016/j.jrtpm.2015.12.001 (accessed on 19 March 2021).

40. Šimral, P. Jak získat potřebnou kapacitu dráhy pro nákladní vlaky hned a bez významných a nákladných opatření?; METRANS Rail s. r. o.: Prague, Czech Republic, 23 June 2013. Unpublished.

41. Vávra, R. Dálková železniční osobní doprava v relacích Praha - Drážd’any/Cheb. Diploma Thesis, Czech Technical University in Prague, Prague, Czech Republic, 18 June 2018. Available online: https://dspace.cvut.cz/handle/10467/77201. (accessed on 22 March 2021).

42. Vávra, R.; Janoš, V. Long-Distance Railway Passenger Transport in Prague - Dresden/Cheb Relations. In Modern Traffic Engineering in the System Approach to the Development of Traffic Networks; Macioszek, E., Sierpiński, G., Eds.; Springer Nature Switzerland AG: Basel, Switzerland, 2020; Volume 1083, pp. 257-274. ISSN 2194-5365. ISBN 978-3-030-34069-8

43. Institut für Regional- und Fernverkehrsplanung, e. K. The Timetable Construction System FBS. Available online: http://www.en.irfp.de/the-timetable-construction-system-fbs.html (accessed on 23 March 2021).

44. Správa železnic. Jízdní řády (platné do 5. 4. 2021). 090 Praha - Ústí nad Labem - Děčín. Prague, Czech Republic, 2020. Available

https://www spravazeleznic.cz/documents/50004227/115131601/k090.pdf/2c5d2750-f47b-45ef-bce8-f5c889ffca5f (accessed on 23 March 2021).

45. Michl, Z. et al. Netgraph - an Efficient Tool for Periodic Timetabling and Capacity Planning. Acta Polytech. CTU Proc. 2017, Volume 11; pp. 29-30, DOI: 10.14311/APP.2017.11.0043, Available online: https://doi.org/10.14311/APP.2017.11.0043 (accessed on 22 March 2021).

46. Ministerstvo dopravy. Plán dopravní obsluhy území vlaky celostátní dopravy. Zásady objednávky dálkové dopravy pro období 2017 2021; Ministerstvo dopravy: Prague, Czech Republic, 2016. Available online: https://www.mdcr.cz/getattachment/Dokumenty/Verejna-doprava/Financni-ucast-statu/Plan-dopravni-obsluhy-uzemi-vlakycelostatni-dopra/Plan-dopravni-obsluhy-uzemi-2017-2021.pdf.aspx (accessed on 22 March 2021).

47. European Commission. Regulation (EU) No 1315/2013 of the European Parliament and of the Council of 11 December 2013 on Union Guidelines for the Development of the trans-European Transport Network and repealing Decision No 661/2010/EU Text with EEA Relevance. European Union: Brussels, Belgium, 2013. Available online: https://eur-lex.europa.eu/legal-content/EN/TXT/?uri=CELEX:32013R1315 (accessed on 24 March 2021).

48. Správa železnic. Tabulky tratových poměrů. TTP 526B. Tabulka 9. Základní provozní údaje pro jízdu vlaku. Účinné od: 15.03. 2021. Správa železnic: Prague, Czech Republic, 2021. Unpublished.

49. Správa železnic. Tabulky tratových poměrů. TTP 527A. Tabulka 9. Základní provozní údaje pro jízdu vlaku. Účinné od: 15. 03. 2021. Správa železnic: Prague, Czech Republic, 2021. Unpublished.

50. Správa železnic. Tabulky tratových poměrů. TTP 544A. Tabulka 9. Základní provozní údaje pro jízdu vlaku. Účinné od: 15. 03. 2021. Správa železnic: Prague, Czech Republic, 2021. Unpublished. 
51. VaV Kap - AnČ, pp. 118-121 Michl, Z. et al. Optimalizace rozvoje železničního systému ČR z hlediska přepravních potřeb. Analytická část. Zpráva o dosažených výsledcích projektu TB0300MD013 řešeného s finanční podporou TA ČR.; taktici.cz, s. r. o. and Czech Technical University in Prague: Prague, Czech Republic, 2016, pp. 118-121. Unpublished.

52. Správa železnic. Sbírka služebních pomůcek pro jízdní řád 2020/21; Správa železnic: Prague, Czech Republic, 2020. Unpublished.

53. European Commission. Consolidated text: Regulation (EU) No. 913/2010 of the European Parliament and of the Council of 22 September 2010 Concerning a European Rail Network for Competitive Freight; European Union: Brussels, Belgium, 2010. Available online: https://eur-lex.europa.eu/legal-content/EN/TXT/?uri=CELEX\%3A02010R0913-20140101 (accessed on 22 March 2021).

54. Ministerstvo dopravy. Plán dopravní obsluhy území vlaky celostátní dopravy. Zásady objednávky dálkové dopravy pro období 2012-2016. Ministerstvo dopravy: Prague, Czech Republic, 2012; p. 33. Available online: https://www.mdcr.cz/getattachment/Dokumenty/Verejna-doprava/Financni-ucast-statu/Plan-dopravni-obsluhy-uzemi-vlakycelostatni-dopra/plan-dopravni-obsluhy.pdf.aspx (accessed on 24 March 2021). 